\title{
Methodology for Performance Analysis of Textile Effluent Treatment Plants in Bangladesh
}

\author{
Mohidus Samad Khan ${ }^{* 1}$, Shoeb Ahmed ${ }^{2}$, Alexandra E. V. Evans ${ }^{3}$, Matthew Chadwick ${ }^{4}$ \\ ${ }^{1}$ Australian Pulp and Paper Institute, Dept of Chemical Engineering, Monash University, Clayton, VIC 3800, Australia \\ ${ }^{2}$ Department of Chemical and Biomolecular Engineering, North Carolina State University, Raleigh. NC 27695, USA \\ ${ }^{3}$ International Water Management Institute, 127 Sunil Mawatha, Pelawatte, Battaramulla, Sri Lanka \\ ${ }^{4}$ Stockholm Environment Institute, University of York, UK
}

Received 01 December 2009; received in revised form 25 December 2009

\begin{abstract}
The efficiency of individual units of an effluent treatment plant (ETP) determines the overall performance of the plant and the final effluent quality. In this study an ETP of a composite textile industry in Bangladesh was investigated using this method. Water samples were collected from the main units of the ETP and were analysed for key parameters. The results were used to diagnose problems with the treatment units and to suggest modifications. From this, a simple but robust methodology was developed for evaluating the performance of the different treatment units and the ETP as a whole that could be implemented by ETP managers on a regular basis to improve the performance so that the effluent leaving the factory meets national standards and conforms to the requirements of international buyers. The results showed that poor management, especially chemical dosing, was seriously affecting the ETP's performance and that simple measures could address the problems.
\end{abstract}

Keywords: Effluent treatment plant (ETP), monitoring, treatment, efficiency, performance, indicators

DOI:10.3329/cerb.v13i2.3939

\section{Introduction}

The ready-made garment sector has become one of the largest manufacturing sectors in Bangladesh with approximately 4490 apparel manufacturing units registered under the Bangladesh Garment Manufactures and Exporters Association (BGMEA) in 2008 [1]. The growth in this sector, and other small and medium scale enterprises, undoubtedly has a positive effect on national economic development but there are also negative implications. In particular, the large volumes of water consumed and the water pollution generated through the dyeing process can have a severe impact on the local environment. Khan et al. [2] reported that a semi-automated composite textile industry of 10 tonne capacity produces $1250 \mathrm{~m}^{3}$ of effluent each day, which contains an assortment of chemicals including salts, dyes and bleaches.

The rapid but unplanned growth of industrial clusters, with several factories discharging large amounts of untreated or poorly treated wastewater, has led to serious localized water pollution. As a result, water bodies and agricultural land are displaying reduced productivity and the biological diversity of these ecosystems is threatened. The result is not only environmental degradation but also a reduction in the nutrition and incomes of families that traditionally depended on these resources; and they are not always

*Corresponding author Email: mohid.khan@ @otmail.com the same people who get benefit from the jobs created by the factories.

One solution is to ensure that all the effluent is properly treated before it is discharged. The Bangladesh Environment Conservation Act (1995) and Rules (1997) make provision for this, categorizing factories according to their ability to pollute and stating the measures that must be taken to address this, including treatment. Under the 1997 Rules fabric dyeing and chemical processing industries are categorized as "Red industries", which is the highest category in the Rules and for which an effluent treatment plant (ETP) is mandatory. Under these Rules factories must treat as well as monitor the quality of their wastewater and stay within national discharge quality standards (Table $1)$.

Table 1: Discharge quality standards for classified industries composite textile plants

\begin{tabular}{|c|c|}
\hline Parameter & Limit $(\mathrm{mg} / \mathrm{l})$ \\
\hline $\mathrm{pH}$ & $6.5-9$ \\
\hline Total Suspended Solid (TSS), (mg/l) & 100 \\
\hline $\mathrm{BOD}_{5} 20^{\circ} \mathrm{C},(\mathrm{mg} / \mathrm{l})$ & $50 / 150^{*}$ \\
\hline $\mathrm{COD}(\mathrm{mg} / \mathrm{l})$ & $200^{* *}$ \\
\hline Oil and Grease, $(\mathrm{mg} / \mathrm{l})$ & 10 \\
\hline Total Dissolved Solid (TDS), (mg/l) & 2100 \\
\hline Waste Water Flow & $100 \mathrm{~L} / \mathrm{Kg}$ of fabric processing \\
\hline \multicolumn{2}{|c|}{ Special parameters based on classification of dyes used } \\
\hline Total Chromium (as Cr molecule), (mg/l) & 2 \\
\hline Sulfide (as S molecule), (mg/l) & 2 \\
\hline Phenolic compounds as $\mathrm{C}_{6} \mathrm{H}_{5} \mathrm{OH},(\mathrm{mg} / \mathrm{l})$ & 5 \\
\hline
\end{tabular}

(C)Bangladesh Uni. of Engg. $\mathcal{G}$ Tech. 
Despite these laws, factories often show a reluctance to invest money in proper treatment because they consider it to be a non-productive use of money in an industry that is still emerging and striving to remain profitable in the highly competitive global market. Even where industries already have ETPs, there is often unwillingness to operate the plant correctly because of the high running costs or a lack of experience to do so effectively.

\section{Project Approach}

In order to address the issues of increasing water pollution from textile industries and inadequate treatment, the project "Managing Pollution from Smalland Medium-Scale Industries in Bangladesh" was initiated. It was funded by the EU Asia Pro Eco Programme and the DFID Knowledge and Research Programme, between 2003 and 2006. The aim of the project was to reduce pollution while maintaining the profitability of the industries and thereby ensure the incomes of the employees as well as the livelihoods of those who depended on the natural resources that were being impacted. The activities therefore involved cleaner production and improved wastewater treatment. The project was implemented by the Stockholm Environment Institute (SEI), the Bangladesh Centre for Advanced Studies (BCAS) and the University of Leeds, UK.

In this component of the project, the team worked with a composite textile industry that had recently introduced an ETP but did not have much experience in operating it. The purpose of the work was three-fold:

1. To assist in diagnosing any problem with the ETP and to advise the factory team in optimal management;

2. To initiate a simple but effective system to regularly check the function of the major components of the ETP in that particular factory and to calculate the overall performance of the system; and

3. To use this to create a generic set of guidelines for other textile factories to develop their own monitoring procedures.

The data collected by the factories could be used to make the process more efficient and cost effective; whilst also providing proof to the Department of Environment that they are complying with the law and to international buyers that they are complying with their corporate environmental responsibility criteria.

\section{Theory and methodology}

There is no single, ideal ETP for a textile dyeing industry but the best options consist of several units. The combination of these units will vary depending on the exact type and function of the processing plant, which is determined to a large degree by the nature of the effluent. Typically an ETP for a textile industry would consist of primary, secondary and tertiary treatment [3] to ensure the best performance; however, in countries where resources are limited and factories must minimize their outgoings, they are less likely to adopt advanced treatment methods. In Bangladesh for example, ion exchange, electro-dialysis and reverse osmosis have only recently been introduced for wastewater treatment and the uptake is still limited.

Consequently the combination of units in an ETP in Bangladesh can vary considerably depending on: the size of the factory; the exact nature of the industrial process and thus the waste being generated; the funds available to construct and operate the ETP; the compliance criteria specified by buyers (if any); and the engineering consultants contracted to design and construct the ETP. This makes is more difficult to create a generic model for monitoring but guidance can be given based on the type of units and the performance standards typically expected for those units.

A combination of physico-chemical and biological units are most commonly used in textile dyeing industries in Bangladesh [4], although pure physicochemical plants have also been observed by the project team. Depending on the combination of phyicochemical and biological units selected the removal efficiency of key constituents differs: the ranges of percentage removal rates are given in Table 2. As can be seen they can vary considerably depending on the type of units (for example a low rate non-submerged trickling filter can achieve a BOD removal efficiency of 80-90 per cent while the range for a high rate system is $65-90$ per cent); the retention time is also an important factor for certain units, such as sedimentation tanks [5].

Table 2: Typical removal rates for ETP components

\begin{tabular}{lll}
\hline Component & Constituent & $\%$ Removal rate \\
\hline Fine screens & BOD & $5-55$ \\
& TSS & $5-55$ \\
\hline Primary sedimentation tanks & BOD & $25-40$ \\
& TSS & $50-70$ \\
& & $\begin{array}{l}\text { Depending on type } \\
\text { and detention time }\end{array}$ \\
& & \\
Biological: & & $50-90$ \\
Trickling filters & BOD & Final effluent quality \\
Activated sludge & BOD and TSS & $10 \mathrm{mg} / \mathrm{l}$ \\
\hline Anaerobic & & $65-95$ \\
\hline Note: removal rate depends on type of system within each category of
\end{tabular}

which there are many.

A typical ETP consists of an entrance-screening unit followed by an equalization tank and the physicochemical unit, which is usually a combination of neutralization, coagulation, flocculation and clarifier (primary clarifier) unit. One or more biological treatment units along with a clarifier are used after the physicochemical treatment units. The number depends on: the 
quality of the influent; the performance of previous units; the type of biological unit; and the efficiency of a single biological unit. Finally, wastewater from the biological unit is treated with filters (generally sand or activated carbon filters) depending on the wastewater quality. Overall an ETP comprised of an appropriate combination of physico-chemical and biological treatment units can remove upwards of 90 per cent of BOD and COD [4].

In addition to BOD, COD and TSS, parameters of importance are colour, odour, total dissolved solids (TDS), turbidity, conductivity, dissolved oxygen (DO), pH, alkalinity, hardness, metals and ions. For biological treatment, microorganisms may be monitored along with sludge volume index (SVI) and stirred sludge volume index (SSVI).

In this study only the parameters considered to be of most importance or which give an indication of overall pollution load (e.g. BOD and COD) were measured. This reflected the type of waste, the national standards, and the facilities and funds that a factory would have available to them for monitoring. Since this method was intended to be repeated regularly it could not be overly complex or expensive.

The units that would be sampled in a standard monitoring programme of a typical ETP are summarized in Table 3 along with the parameters that would be analysed for. Monitoring just a few simple parameters may facilitate the assessment of the performance of the whole plant, if done in an effective and systematic way [6].

Table 3: List of parameters to be checked at different sampling points

\begin{tabular}{|c|c|c|}
\hline Unit & Parameters & Sampling point \\
\hline Equalization tank & $\begin{array}{l}\mathrm{pH}, \mathrm{TDS}, \mathrm{TSS}, \mathrm{BOD}, \mathrm{COD}, \\
\text { Temperature }\end{array}$ & Outflow \\
\hline $\begin{array}{l}\text { Neutralization } \\
\text { tank }\end{array}$ & $\mathrm{pH}$ & $\begin{array}{l}\text { Outlet, to ensure that } \\
\text { the acid or alkali has } \\
\text { been properly mixed }\end{array}$ \\
\hline $\begin{array}{l}\text { Coagulation and } \\
\text { Flocculation }\end{array}$ & $\mathrm{pH}$ & Outlet \\
\hline Primary Clarifier & TSS, TDS, COD, pH, BOD & Outflow \\
\hline Biological Reactor & $\begin{array}{l}\mathrm{DO}, \mathrm{pH} \text {, samples of activated } \\
\text { sludge for microscopic exami- } \\
\text { nation, } \\
\text { Temperature }\end{array}$ & In aeration basin \\
\hline $\begin{array}{l}\text { Secondary Clari- } \\
\text { fier }\end{array}$ & $\mathrm{BOD}, \mathrm{COD}, \mathrm{TSS}$ & Outflow \\
\hline Treated Water & $\mathrm{pH}$, TDS, TSS, BOD, COD & Outlet \\
\hline
\end{tabular}

The factory in which the research was conducted undertakes knitting, dyeing and sewing of cotton (usually referred to as a composite factory); it has a daily production capacity of 10 tonnes which is split between dark colours (35 per cent), medium shades (15 per cent), light shades (30 per cent) and bleached whites (20 per cent).

The factory has a conventional ETP with physicochemical and biological units as shown in Figure 1. The major units of the ETP were selected for sampling as indicated in Figure 1 and described in Table 4.
Two sets of samples were collected from each of these points: one set was collected in the morning and the other set in the evening. The samples were preserved below $4^{\circ} \mathrm{C}$ and transported to the analytical laboratory as quickly as possible to minimize the effect of spontaneous chemical reactions and microbial activity in the samples. Samples testing started within $24 \mathrm{hrs}$ of collection.

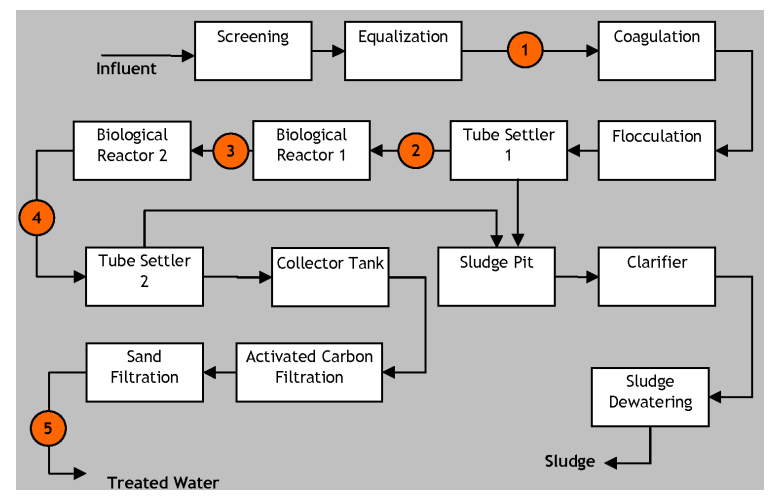

Figure 1: Block diagram of a model ETP

Table 4: List of sampling location and objective of the sampling

\begin{tabular}{|c|c|c|}
\hline $\begin{array}{l}\text { Sample } \\
\text { ID }\end{array}$ & $\begin{array}{l}\text { Location of } \\
\text { Sampling }\end{array}$ & Objective \\
\hline 1 & $\begin{array}{l}\text { Outflow of } \\
\text { Equalization } \\
\text { Tank }\end{array}$ & $\begin{array}{l}\text { To find out the effluent (untreated) wa- } \\
\text { ter characteristics (after equalization and } \\
\text { before P-C) }\end{array}$ \\
\hline 2 & $\begin{array}{l}\text { Outflow of } \\
\text { Tube Settler-1 }\end{array}$ & $\begin{array}{l}\text { To analyze the performance of Coagula- } \\
\text { tion and Flocculation units }\end{array}$ \\
\hline 3 & $\begin{array}{l}\text { Outlet of } \\
\text { Biological } \\
\text { Reactor-1 }\end{array}$ & $\begin{array}{l}\text { To analyze the performance of Biologi- } \\
\text { cal Reactor-1 }\end{array}$ \\
\hline 4 & $\begin{array}{l}\text { Outlet of } \\
\text { Biological } \\
\text { Reactor-2 }\end{array}$ & $\begin{array}{l}\text { To analyze the performance of Biologi- } \\
\text { cal Reactor- } 2\end{array}$ \\
\hline 5 & $\begin{array}{l}\text { Outlet of ETP } \\
\text { (treated water) }\end{array}$ & $\begin{array}{l}\text { To analyze the performance of Tube } \\
\text { Settler-2, Activated Carbon Filter and } \\
\text { Sand Filter. } \\
\text { Also to check whether the discharge wa- } \\
\text { ter is compliant with Bangladesh legisla- } \\
\text { tion or not. }\end{array}$ \\
\hline
\end{tabular}

It should be noted that due to the nature of the dyeing process, which can take between six and twelve hours, the effluent reaching the treatment plant can vary throughout the day. The samples collected were therefore a composite of several dying batches which had been combined in the equalization tank. The assumption is that the equalization tank is of sufficient capacity and well mixed enough to ensure the effluent passing through the system is of consistent quality $[7,8]$. It is also assumed that the dyeing operations taking place do not vary significantly enough for this to effect quality over the period being studied. These are large assumptions but it is normal for such assumptions to be made in routine monitoring of an ETP and is also a pragmatic approach when effluent treatment is an additional activity to the core business of the industry, and one that rarely results in increased profit. 
Five key parameters were selected for analysis: $\mathrm{pH}$; TDS; TSS; $\mathrm{BOD}_{5}$ and COD, because they are included in the discharge quality standards for textile industries in Bangladesh and they are the parameters most commonly used to monitor ETP performance.

\section{Results}

In this study two sampling events were undertaken and the analysis of the results is preliminary. However, the result analysis provides the ETP managers an initial indication of how the results can effectively be used to monitor the performance of the treatment plant.

There was an improvement in all parameters except TDS from the inflow of the treatment plant to the outflow. Some were however still outside the discharge quality standards for textile industries in Bangladesh, including TDS, $\mathrm{BOD}_{5}$, and COD (Table 5 and Table $6)$.

Table 5: Results for morning analysis

\begin{tabular}{|c|c|c|c|c|c|c|c|c|}
\hline Parameters & Units & $\begin{array}{l}\text { Bangladesh } \\
\text { Standards }\end{array}$ & 1 & 2 & 3 & 4 & 5 & $\begin{array}{r}\text { Pollution load } \\
\text { removed }(\%)\end{array}$ \\
\hline$\overline{\mathrm{pH}}$ & - & $6.5-9$ & 9.44 & 9.76 & 9.82 & 7.68 & 7.71 & \\
\hline TDS & $\mathrm{mg} / \mathrm{l}$ & 2100 & 4395 & 4301 & 4819 & 5196 & 5550 & -26.3 \\
\hline TSS & $\mathrm{mg} / \mathrm{l}$ & 100 & 92 & 58 & 31 & 54 & 65 & 2 \\
\hline $\mathrm{BOD}_{5}$ & $\mathrm{mg} / \mathrm{l}$ & $50(/ 150 *)$ & 1000 & 450 & 350 & 240 & 195 & 80. \\
\hline $\mathrm{COD}$ & $\mathrm{mg} / \mathrm{l}$ & 200 & 1287 & 648 & 510 & 364 & 291 & 77.4 \\
\hline
\end{tabular}

Table 6: Results for evening analysis

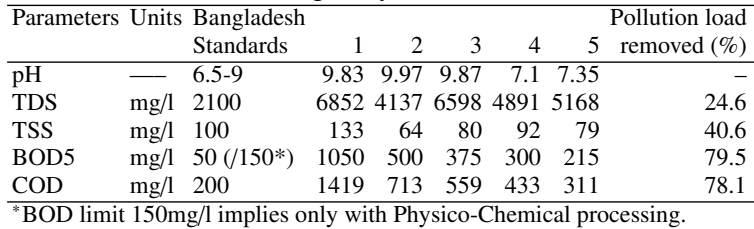

\section{1. $p H$}

At the inflow to the first biological reactor (point 2) the $\mathrm{pH}$ was outside the limits required for bacterial growth which are between $\mathrm{pH} 4.0$ and 9.5 with an optimal range of $\mathrm{pH} 6.5$ - 7.5 [7]. The desired $\mathrm{pH}$ was reached only after the second biological reactor which means that the $\mathrm{pH}$ is likely to have impacted negatively on biological activity in the treatment units (Figure 2).

\section{2. $T D S$}

The TDS values were high and remained so throughout the process (Figure 3 ). They varied greatly throughout the course of the evening monitoring period and in the morning sampling they actually increased rather than decreased through the system. As a result the TDS value in the treated water was at least

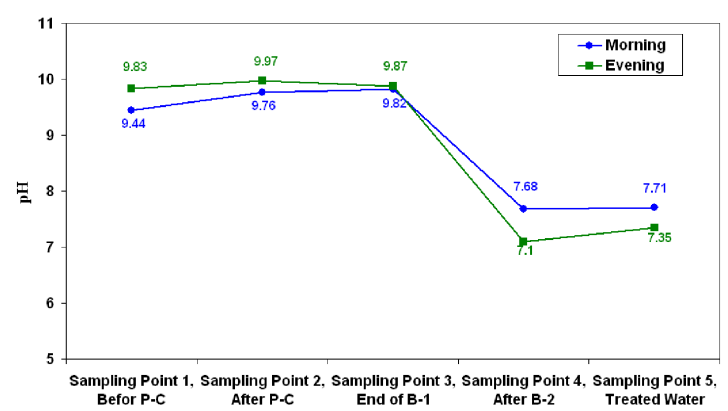

Figure 2: The $\mathrm{pH}$ at different stages of the ETP

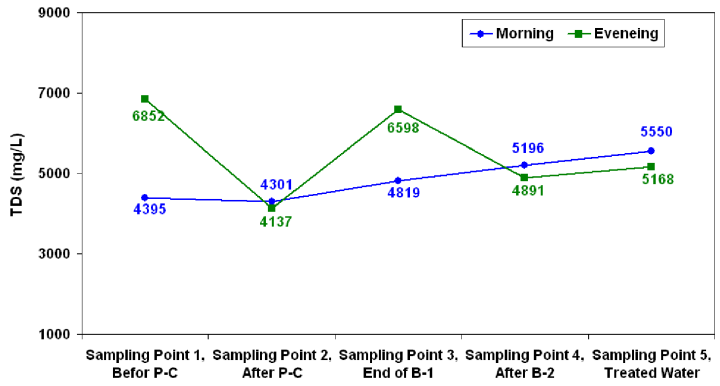

Figure 3: TDS at different stages of the ETP

double the Bangladesh standards for TDS of 2100 $\mathrm{mg} / \mathrm{l}$.

Overall there was a 24 per cent reduction in TDS in the evening and a 26 per cent increase in the morning. The main increase was observed in the first biological unit - the difference between the outflow from physicochemical units, and the outflow of the first biological unit i.e. between sampling points 2 and 3 (Figure 4)

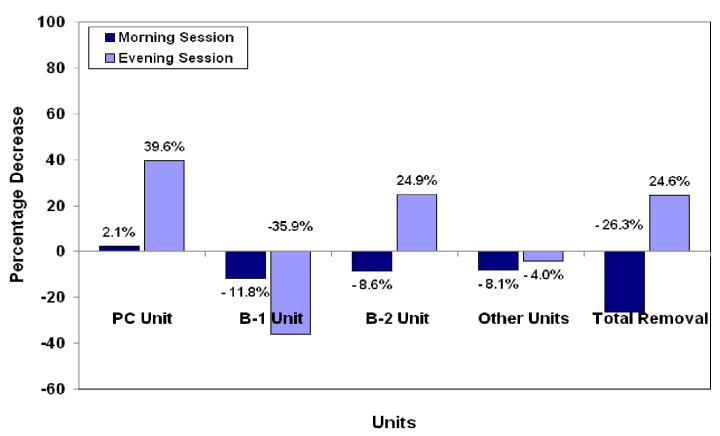

Figure 4: Percentage TDS removal in different stages of the ETP

\section{3. $B O D$ and $C O D$}

The trends observed for $\mathrm{BOD}_{5}$ and COD had similar characteristics to each other, both in the morning and evening. A significant reduction was observed in both parameters from the inflow to the outflow (Figure 5). However, the effluent quality still did not meet the 
Bangladesh standards of $50 \mathrm{mg} / \mathrm{l}$ for $\mathrm{BOD}_{5}$ and 200 $\mathrm{mg} / \mathrm{l}$ for COD (Table 1).

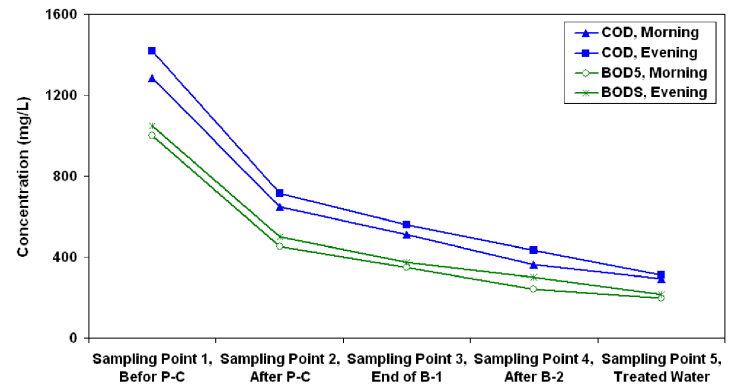

Figure 5: The $\mathrm{BOD}_{5}$ and COD at different stages of the ETP

The most dramatic reduction in $\mathrm{BOD}_{5}$ was observed after the flocculation and coagulation stage in which 52-55 per cent was removed (Figure 6). This represents a satisfactory performance of the physicochemical units although it can be generally expected that a well run physico-chemical unit can remove 5080 per cent of total $\mathrm{BOD}_{5}$ [7]. The biological reactors performed poorly reducing the $\mathrm{BOD}_{5}$ value by only 7-12 per cent.

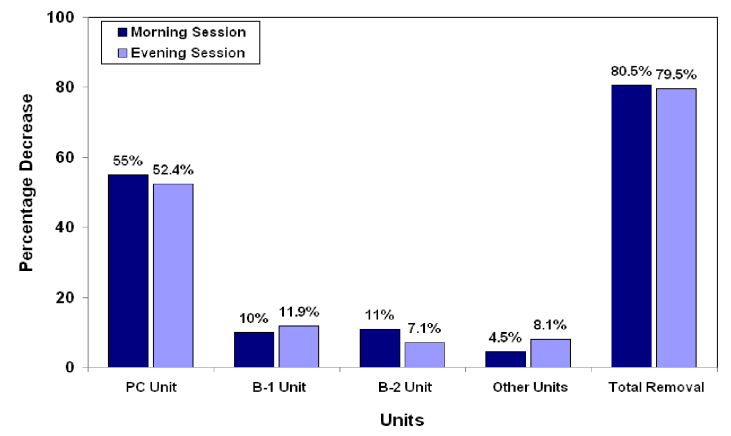

Figure 6: The $\mathrm{BOD}_{5}$ removal in different stages of the ETP

The situation was very similar for the COD with the biological reactors apparently underperforming (Figure 7).

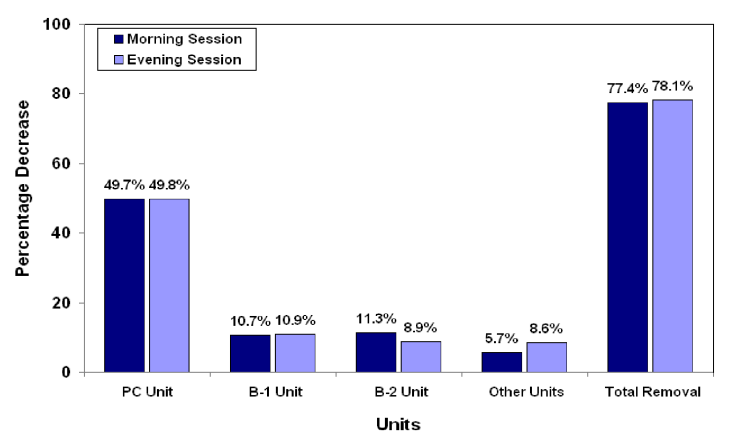

Figure 7: The COD removal in different stages of the ETP

A typical ETP consisting of physico-chemical and biological units can remove 90 per cent or more of the
BOD or COD present in the initial influent, when the ETP is operated efficiently [4]. After a series of treatment this ETP removed approximately 80 per cent of the $\mathrm{BOD}_{5}$ load (Figure 6) and 78 per cent of the COD load (Figure 7), which was not good enough to meet the national (BD) or international (e.g. US EPA) standards [4, 9].

\section{Discussion}

\subsection{Sample factory}

The overall performance of the ETP is inadequate to meet the national discharge quality standards and therefore requires immediate interventions to address the problems. Many of these may be management rather than structural and should therefore not require any significant financial outlay by the factory, in fact better management of the plant could actually reduce costs.

A major issue that needs to be addressed in the equalization tank is the $\mathrm{pH}$. The dosing of an acid (usually hydrochloric acid) would lower the $\mathrm{pH}$ and thus bring it to within the limits required for biological activity which would help to ensure a healthy population of bacteria in the two biological treatment units. This would result in an overall improvement in the treatment, particularly in the reduction of organic matter, measured as BOD which needs to be reduced further in order to meet the national standards.

The TSS values of the influent were below the national standard and remained low during the treatment process. This is unsurprising as the effluent from textile dyeing processes generally has low TSS.

Total dissolved solids are a particular problem for textile dyeing industries because a large quantity of salt is required in the process, all of which is disposed of with the final effluent. The TDS values in the sample factory showed considerable variation throughout the treatment process. This may be a result of different influxes of chemicals discharged over the course of the dyeing process and the factory should check this more regularly so that they better understand their waste and can manage the treatment better.

It would however be expected that the equalisation tank would lessen the variation, which suggests that the equalisation tank may not be of sufficient capacity or have a long enough retention time. The TDS values also increased at some stages of the treatment process (Figure 4). These increases appear to be associated with chemical dosing to the treatment plant (in this case possibly nutrients in the biological treatment unit) which implies that the ETP operator is adding excessive quantities of chemicals. It may also relate to the dosing of incompatible chemicals and the underperformance of the biological reactor, which in turn is in part due to the poor control of $\mathrm{pH}$. 


\subsection{Implications for other factories}

The monitoring programme used in this factory was simple and quick, yet it clearly highlighted some significant problems with the management of the system that were having a detrimental impact on its efficiency. As expected it aided the identification and diagnosis of problems within certain units. This is of far greater benefit to the ETP manager than the knowledge that the ETP is not meeting national standards.

It is essential that the $\mathrm{pH}$ in the biological units is maintained between $\mathrm{pH} 4$ and 9.5 and ideally between 6.5 and 7.5 if the bacteria are to remain alive and active and thus treat the waste. This is reasonably simple to achieve if an automatic monitoring and dosing system is installed. Monitoring and dosing can be done manually but it is far more efficient and practical to install such a system because the $\mathrm{pH}$ can fluctuate significantly throughout the day, depending on the processes in the factory.

The dosing of other chemicals must also be correct otherwise the TSS and TDS may not be reduced, and may even increase. Managers of ETPs should regularly monitor the units in the plant where chemical dosing takes place so that they know their waste and can be more accurate in their dosing of chemicals. It is also good practice to perform laboratory jar tests on different types of waste from the factory for the same reason.

Although the $\mathrm{BOD}_{5}$ and $\mathrm{COD}$ reduced through the system the concentrations were still above the national standards in the final effluent. This means that there is scope for improvement through better operation of the plant. It may be necessary to ensure that the biological reactors are adequately aerated and that the correct nutrient composition is being added to "feed" the bacteria, as textile effluent contains very little of the nutrients, including nitrogen and phosphorus, required for a healthy and active bacterial population. Maintaining the purity of the chemical nutrients used is also very important in order to avoid an increase in TDS. Factory treatment plants could potentially be modified to receive urine from the toilets (or the liquid portion of septic tanks), which would provide the nutrients without the needs for chemical dosing (although further steps may be required for pathogen removal if the urine is not separated from the faeces at source).

\section{Conclusions}

In Bangladesh and other countries in the region effluent treatment from textile dyeing factories and other industrial processes is usually required by law and often expected by international buyers. Despite this, treatment is regularly below standards and is rarely checked either by the factory, environment departments or buyers. There are a several reasons for this but the bottom line is usually a lack of funds and technical expertise. These reasons are also why factories have been found to run their ETPs sub-optimally. This study shows that through the process of simple monitoring of key parameters at strategic places in the treatment plant, the ETP manager would be able to optimize the treatment process and potentially save money by reducing the chemicals and energy needed to run the system.

The main problems experienced by factories with ETPs are inadequate treatment due to incorrect dosing of chemicals required in the treatment process or inactivity and even death of necessary micro-organisms, due to the $\mathrm{pH}$, insufficient oxygen or lack of nutrients. All of these can be addressed through better management; usually chemical dosing. By regularly monitoring and understanding their wastewater properly ETP managers can make effective decisions to achieve optimal ETP functioning.

Furthermore, factories supplying international buyers can use this data to demonstrate their 'green' credentials and thus generate more business or at the very least maintain their share in an increasingly competitive market.

\section{Acknowledgment}

The authors would like to thank Dr J. Knapp, Leeds University, UK and Dr M. Sharif, BCAS for their valuable technical suggestions in the project activities.

\section{References}

[1] Bangladesh Garment Manufacturers and Exporters Association, Homepage: http://bgmea.com.bd, Cited: 8 December 2008

[2] Khan M, Knapp J, Clemett A and Chadwick M, Managing Pollution from Small Industries in Bangladesh, Technical report, Research for Development, Department for International Development (DFID), 2006

[3] Lash D and Kominek E, Industrial Wastewater and Solid Waste Engineering, Ch. Primary-Waste-Treatment Methods, McGraw-Hill, New York, 1980. pp. 81-123

[4] Ali M, Ahmed S and Khan M, Characteristics and Treatment Process of Wastewater in a Nylon Fabric Dyeing Plant, Journal of Chemical Engineering, The Institute of Engineers, Bangladesh, 2005. ChE23(1):pp. 17-22

[5] Crites R and Tchobanoglous G, Small and Decentralized Wastewater Management Systems, McGraw-Hill, New York, 1998

[6] Khan M, Knapp J, Clemett A, Chadwick M and Mahmood M, Managing and Monitoring Effluent Treatment Plant, Managing Industrial Pollution from Small and Medium Scale Industries in Bangladesh Booklet Series, SEI, BCAS, University of Leeds, Dhaka, Bangladesh, 2006

[7] Tchobanoglous G, Burton FL and Stensel HD, Wastewater Engineering: Treatment and Reuse, McGraw-Hill, New York, 4th edition, 2003

[8] Noyes R, Unit Operation in Environmental Engineering, Noyes Publications, New Jersey, USA, 1994

[9] Sharif MI and Hannan MA, Guide to the Environmental Conservation Act 1995 and Rules 1997, Bangladesh Centre for Advanced Studies (BCAS), Dhaka, Bangladesh, 1999 